\title{
Shakespeare and the Bible
}

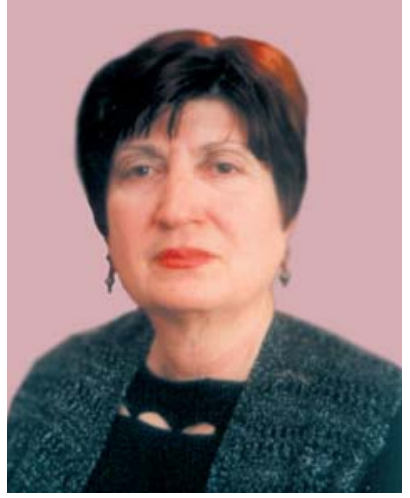

Sona Seferyan
66 $\mathbf{C}$ hakespeare and no end” wrote Goethe (1815) $\checkmark$ and his words always sound prophetic.

The history of the Armenian translations of Shakespeare falls under three periods. They, in commemoration, bear the name of the Armenian classic translator Hovhannes Massehian who opened a new era in the Armenian Art of Translation. He was the first to pay attention to Shakespearean imagery and biblical allusions throughout his twelve plays in translation. They are: Hamlet, As You Like It, Romeo and Juliet, The Merchant of Venice, King Lear, Othello, Macbeth, Coriolanus, Julius Caesar, Antony and Cleopatra, Much Ado About Nothing, The Tempest. One thing of great importance is worth mentioning here. Why did we, Armenians, turn to Shakespeare centuries before to find answers to the everlasting problems of the nation in his works? We have studied and translated numerous world famous men of letters but this love of ours towards the great thinker is unique. The answer is here, in the prophetic sentence of the Armenian poet of the 20th century: 'Your Narekatsi, Our Shakespeare'(Paruir Sevak). Narekatsi is a 10th- century scholar whose ode to God "The Book of Lamentations" is widely known all over the world. Both the thinkers are nourished by the Bible, both the scholars' languages are Indo-European and while studying their works the similarity and likeness of the theme, its interpretation and way of thinking through biblical allusions become apparent (mainly the Book of Job, the Psalms and the Books of the Prophets).

Shakespeare's characters such as Hamlet, Desdemona, Cordelia undertake the role of a scapegoat and their death puts everything to their places for the time being.

1. Hamlet's universal statement

The time is out of joint: - O cursed spite

That ever I was born to set it right! (I, 5) is always up-to-date.

The axis of the Bible is the relationship between Man and God, whereas Shakespeare's is the relationship between Man and Man and God is always there as wisdom, justice, and judgement and equity. (Prov. 1.3)

What a piece of work is man! how noble a reason! how infinite in faculties! in form and moving, how express and admirable in action, how like an angel! in apprehension, how life a god! the beauty of the world! the paragon of animals! and yet, to me, what is this quintessence of dust? (II, 2)

This idea is dominant both in the Bible and in Shakespeare's works but whoever and whatever you are, from dust you come to dust you return. Throughout Hamlet the tiny 
worm is an emperor, and we fat ourselves to maggots (IV, 3) and the funeral bak'd meats/ Did coldly furnish forth the marriage tables (I,2).

2. This Happy Comedy As You Like It reveals the golden world where all the characters enjoy themselves in the Forest of Arden and the imagery of British Nature with blossoming or rotten trees is everlasting. Behold these three years I come seeking fruit on this fig tree, and find none: cut it down; why cumbereth it the ground? (Luke 13.7)

3. The tragedy Romeo and Juliet is absorbed with divine light: and God said, Let there be light: and there was light. (Gen. 1.3)

And the eternal maxim In the beginning was the Word, and the Word was with God, and the Word was God (John 1.1) is the favourite wisdom of Shakeapeare's, whose works are a great feast of languages, his characters - orthographers, his words - sweet smoke of rhetoric. But Love, the eternal Love is always in the Trinity as charity and now abideth faith, hope, charity, these three; but the greatest of these is charity. (1Cor.13.13)

His words are like daggers (Hamlet, II, 4) and this goes to a wholesome tongue is a tree of life: but perverseness therein is a breach in the spirit. (Prov,15.4)

4. The Merchant of Venice touches upon the Christian - Jew problem. The Jew is an old carrion with fangs. Shylock protests against being called a dog. The dog is mentioned in the Old and New Testaments, in the Book of Psalms, in the first and second Books of Kings as an embodiment of envy, gluttony and blasphemy: Give not that which is holy unto the dogs (Mat.7.6)

5. King Lear is a fairy-tale with a king, a kingdom and three daughters. Every kingdom divided against itself is brought to desolation; and a house divided against a house falleth. (Luke, 11.17)

The play on words I and eye is one of the central images of the tragedy together with the images of disease, plague, sore, embossed carbuncle, corrupted blood (II, 4). If man has no inner eye he is doomed to perish. When the king lost his eyesight he saw and understood the universe and mankind.

6. In Othello the colours white and black work all the time together with the divine truth For Love strong as death; jealousy is cruel as the grave (Solom.'s Song, 8.6) and jealousy 'tis a monster / Begot itself, born on itself (IV,1).

7. Macbeth's illness is unnatural and at the same time a great perturbation in nature and good things of day begin to droop and drowse (III, 2) and this my hand will rather / The multitudious seas incarnadine, / Making the green one red (II,1) is an allusion to Take thy rod, and stretch out thine hand upon the waters of Egypt, upon their streams, upon their rivers, and upon their ponds, and upon all their pools of water, that they may become blood (Ex.8.19).

8.9.10. In the Roman tragedies Coriolanus, Antony and Cleopatra, Juluis Caesar events take place in pre-Christian times but the imagery alluded to the Bible is obvious. Assassination, death, evil - everywhere, on earth and in man's soul, accordingly, the same happens after each assassination: And the graves were opened; and many bodies of the saints which slept arouse (Matt. 28.52).

11. Much Ado About Nothing summarises all the imagery dear to the author. People 
here are busy with fishing, hunting, sowing, planting and they are happy. Here the image of the smell is purity - smoke a musty room (I, 3) alluding to And another angel came and stood at the altar, having a golden censer; and there was given unto him much incense, that he should offer it with the prayers of all saints upon the golden altar which was before the throne (Rev.8.3).

12. The Tempest foresees the new world, new people all goodly, beauteous, brave $(\mathrm{V}, 1)$. Shakespeare, having written so much, having come to the idea Vanity of Vanities and vexation of the soul, leaves London for his native town to die there as solitary as a swan, the swan of Stratford, thinking the rest is silence and like Prospero, the Duke of Milan, utters his last: And my ending is despair / Unless I be relieved by prayer (Epilogue).

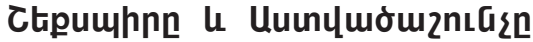

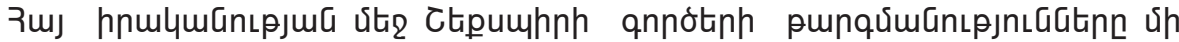

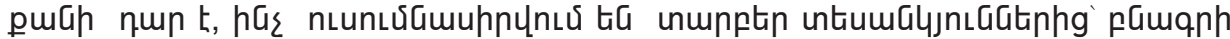

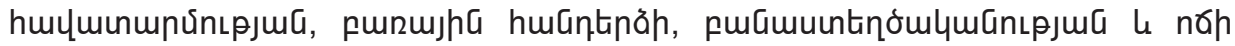
щмm

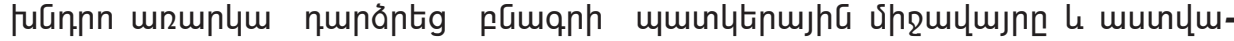

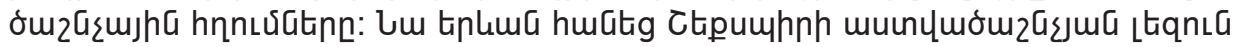

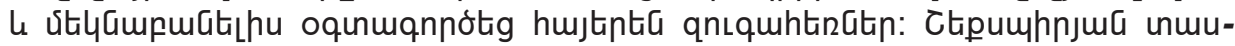

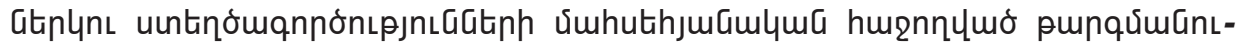

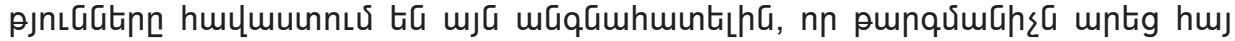

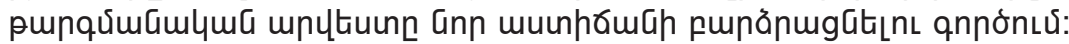

